IRA-International Journal of Education \& Multidisciplinary Studies ISSN 2455-2526; Vol.05, Issue 03 (2016)

Pg. no. $140-146$

Institute of Research Advances

http://research-advances.org/index.php/IJEMS

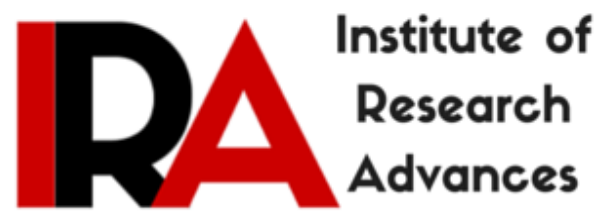

\title{
A Comparative Study of Anthropometric and Psycho-Motor Abilities of Sub-Junior National Level Boxers
}

\author{
${ }^{1}$ Sumitra Kirtania, ${ }^{2}$ Pintulal Mondal and ${ }^{3}$ Dr. Mahesh Sawata Khetmalis \\ ${ }^{1}$ Asst. Boxing Coach of SAI and Ph.D. Scholar, \\ Visva Bharti, Santiniketan, West Bengal, India. \\ ${ }^{2}$ Ph.D. Scholar, Visva Bharti, Santiniketan, West Bengal, India. \\ ${ }^{3}$ Associate Professor Visva Bharti, Santiniketan, West Bengal, India.
}

Type of Review: Peer Reviewed.

DOI: http://dx.doi.org/10.21013/jems.v5.n3.p1

\section{How to cite this paper:}

Kirtania, S., Mondal, P., \& Khetmalis, M. (2016). A Comparative Study of Anthropometric and Psycho-Motor Abilities of Sub-Junior National Level Boxers. IRA International Journal of Education and Multidisciplinary Studies (ISSN 2455-2526), 5(3), 140-146. doi:http://dx.doi.org/10.21013/jems.v5.n3.p1

(C) Institute of Research Advances

(cc) EY-NC

This work is licensed under a Creative Commons Attribution-Non Commercial 4.0 International License subject to proper citation to the publication source of the work.

Disclaimer: The scholarly papers as reviewed and published by the Institute of Research Advances (IRA) are the views and opinions of their respective authors and are not the views or opinions of the IRA. The IRA disclaims of any harm or loss caused due to the published content to any party. 


\section{ABSTRACT}

The aim of this study is to identify the Anthropometric and profiles of sub-Junior National level Boxers and also to find out the relationship of Anthropometric profiles and psychomotor abilities of the sub-Junior National level Boxers. A total 22 female Boxers $(11$ medalists and 11 non-medalists) age range between $12^{\text {th }}$ to $16^{\text {th }}$ years will be select from SAI, SAG, Imphal centers. Selected Anthropometric variables (Body composition) will be taken on each Boxer. Total Psychomotor ability scores (Speed, Agility, Differentiation, Orientation, Balance, Rhythm Ability) will be taken. For interpretation of data a comparative analysis of the selected variable, the " $t$ " test was applied. The data of both groups were collected separately for all the variables. Statistic such as mean and standard deviation was computed. The level of significance was set at 0.05. It was found that in BMI, BMR do not have significant deference between the Manipur and West Bengal female Boxers and significant deference was found on Speed, Agility, Differentiation, Orientation, Balance, Rhythm Ability.

Keywords: Anthropometric variables, psychomotor abilities of Sub-Junior National level female Boxers.

\section{Introduction}

Games and sports, as a part of human education have always existed in the human society. "Sports by their very name are enjoyable, challenging all absorbing and required a certain amount of skills and physical fitness". Sports have very prominent role in modern society. Today sports have become an inseparable phenomenon of our social life. It is important an individual, a group, a nation and indeed the world. As it is well understood, "Fit body fit nation". Sports have ever reflected development in society. Sports indeed, have been a mirror of society.

Anthropometry is an important aspect of sports medicine. Anthropometric dimensions and morphological characteristics play an important role in determining the success of a sportspersons (RecoSanz, 1998; Wilmore \& Costill, 1999; Keogh, 1999). It has been well established that specific physical characteristics or anthropometric profiles indicate whether the player would be suitable for the competition at the highest level in a specific sport (Claessens et al., 1999; Bourgois et al., 2000; Reilly et al. 2000; Gabbett, 2000; Ackland et al., 2003; Slater et al., 2005;). These anthropometric and morphological parameters are the sensitive indicators of physical growth and nutritional status of the sportspersons for their maximal performances (Wilmore \& Costill, 1999; Chatterjee et al., 2006). The evaluation of body composition permits quantification of the major structural components of the body muscle, bone and fat. With respect to health fitness, it refers to the percentage of body weight that is composed of fat as compared with fat-free or lean tissue.

The theory of motor coordination is the basis for understanding the motor of coordination abilities. Motor coordination is part and parcel of actions regulation. Coordination abilities have also important and strong links with the motor skills as the motor coordination focus the basis of both. These abilities enable the sportsperson to do a group or set of movement with better quality and effect. Psychomotor abilities enable the sports man to do a group of movements with better quality and effect. The speed of learning of skill and its stability is directly dependent on the level of various coordinative abilities. They are needed for maximal utilization of conditional abilities, technical skills and tactical skills (Hardayal Singh, 1991).

Boxing is an excellent vehicle for development of physical fitness and that boxing-related activities are being widely used in attempts to address the global problem of increasing incidence of diseases caused by sedentary lifestyles. Boxing depend to a large extent on technical skill and tactics. Beside these the endurance, agility, reaction ability, flexibility, speed of movement, balance and rhythm are the abilities which are important for achieving good performance in Boxing. 


\section{Objective of the Study}

The study deals with immediate objectives and certain goals as follows.

1. To compare the Fat\%, BMI, BMR, Speed, Agility, Differentiation, Orientation, Balance and Rhythm Ability of Manipur and West Bengal sub-junior female Boxers.

2. To find out the dominance of Fat\%, BMI, BMR, Speed, Agility, Differentiation, Orientation, Balance and Rhythm Ability between Manipur and West Bengal sub-junior female Boxers.

\section{Methodology}

A sample of 22 sub-junior female boxers was selected as subject (11 from Manipur and 11 from West Bengal) from SAI, SAG center in Imphal, Manipur and Bhabanipur boxing club Kolkata, West Bengal. The ages of the player were 12-16 years.

Test Applied:- The data were collected with the help of Body Composition Monitor with Scale HBF-361 is used to measure percentage of fat, BMI, BMR, 50 Mts. shuttle run, differentiation ability test, orientation ability test, balance test and rhythm ability test as standard procedure.

Methods of Analysis: - To analysis collected data "T" test was applied to find out the significant difference between Manipur and West Bengal sub-junior female Boxers.

\section{Discussion of Findings:-}

\section{Table-1}

SIGNIFICANCE OF MEAN DIFFERENCE BETWEEN MANIPUR AND WEST BENGAL SUB-JUNIOR FEMALE BOXERS ON THE FAT\%

\begin{tabular}{|l|l|l|l|l|}
\hline Group & Sample & Mean & SD & "t” \\
\hline MANIPUR & 11 & 25.10 & 2.61 & 2.990 \\
\hline WEST BENGAL & 11 & 27.68 & 1.16 & \\
\cline { 1 - 3 }
\end{tabular}

*Significance at 0.05 level of significance i.e., $=1.725$

A perusal of table -1 indicates that a mean and standard deviation values with regard to Manipur boxers on Fat\% variable were 25.10 and 2.61 whereas in case with West Bengal the same were recorded as 27.68 and 1.16 respectively. There significant difference was found between Manipur and West Bengal as the calculated t-value (2.990) was more than tabulation t-value (1.725) at 0.5 level.

\section{Table-2}

SIGNIFICANCE OF MEAN DIFFERENCE BETWEEN MANIPUR AND WEST BENGAL SUB-JUNIOR FEMALE BOXERS ON THE BMI

\begin{tabular}{|l|l|l|l|l|}
\hline Group & Sample & Mean & SD & "t” \\
\cline { 1 - 2 } & 11 & 21.88 & 1.46 & 0.693 \\
\cline { 1 - 3 } WEST BENGAL & 11 & 21.47 & 1.30 & \\
\hline
\end{tabular}

*Significance at 0.05 level of significance i.e., $=1.725$

A perusal of table -2 indicates that a mean and standard deviation values with regard to Manipur boxers on BMI variable were 21.88 and 1.46 whereas in case with West Bengal boxers the same were recorded as 21.47 and 1.30 respectively. There was no significant difference found between Manipur and West Bengal as the calculated t-value (0.693) was less then tabulation t-value (1.725) at 0.5 level. 
Table-3

SIGNIFICANCE OF MEAN DIFFERENCE BETWEEN MANIPUR AND WEST BENGAL SUB-JUNIOR FEMALE BOXERS ON THE BMR

\begin{tabular}{|l|l|l|l|l|}
\hline Group & Sample & Mean & SD & "t” \\
\hline MANIPUR & 11 & 1211.36 & 120.96 & 0.620 \\
\hline WEST BENGAL & 11 & 1243.36 & 121.01 & \\
\hline
\end{tabular}

*Significance at 0.05 level of significance i.e., = 1.725

A perusal of table -3 indicates that a mean and standard deviation values with regard to Manipur boxers on BMR variable were 1211.36 and 120.96 whereas in case with West Bengal boxers the same were recorded as 1243.36 and 121.01 respectively. These were no significant difference found between Manipur and West Bengal as the calculated t-value (0.620) was less then tabulation t-value (1.725) at 0.5 level.

Table-4

SIGNIFICANCE OF MEAN DIFFERENCE BETWEEN MANIPUR AND WEST BENGAL SUB-JUNIOR FEMALE BOXERS ON THE 50 MTS RUN

\begin{tabular}{|l|l|l|l|l|}
\hline Group & Sample & Mean & SD & "t"' \\
\hline MANIPUR & 11 & 7.72 & 0.39 & 2.681 \\
\hline WEST BENGAL & 11 & 8.18 & 0.39 & \\
\cline { 1 - 3 }
\end{tabular}

*Significance at 0.05 level of significance i.e., $=1.725$

A perusal of table -4 indicates that a mean and standard deviation values with regard to Manipur boxers on $50 \mathrm{mts}$ variable were 7.72 and 0.39 whereas in case with West Bengal the same were recorded as 8.18 and 0.39 respectively. There significant difference was found between Manipur and West Bengal as the calculated t-value (2.681) was more than tabulation t-value (1.725) at 0.5 level.

Table-5

SIGNIFICANCE OF MEAN DIFFERENCE BETWEEN MANIPUR AND WEST BENGAL SUB-JUNIOR FEMALE BOXERS ON THE SHUTTEL RUN

\begin{tabular}{|l|l|l|l|l|}
\hline Group & Sample & Mean & SD & "t”' \\
\hline MANIPUR & 11 & 10.72 & 0.37 & 4.888 \\
\hline WEST BENGAL & 11 & 11.31 & 0.12 & \\
\hline
\end{tabular}

*Significance at 0.05 level of significance i.e., = 1.725

A perusal of table -5 indicates that a mean and standard deviation values with regard to Manipur boxers on shuttle run variable were 10.72 and 0.37 whereas in case with West Bengal the same were recorded as 11.31 and 0.12 respectively. There significant difference was found between Manipur and West Bengal as the calculated t-value (4.888) was more than tabulation t-value (1.725) at 0.5 level.

Table-6

SIGNIFICANCE OF MEAN DIFFERENCE BETWEEN MANIPUR AND WEST BENGAL SUB-JUNIOR FEMALE BOXERS ON THE DIFFERENCIATION ABILITY

\begin{tabular}{|l|l|l|l|l|}
\hline Group & Sample & Mean & SD & "t" \\
\hline MANIPUR & 11 & 25.45 & 3.61 & 4.407 \\
\cline { 1 - 4 } WEST BENGAL & 11 & 18.63 & 3.64 & \\
\cline { 1 - 3 }
\end{tabular}

*Significance at 0.05 level of significance i.e., $=1.725$ 
A perusal of table -5 indicates that a mean and standard deviation values with regard to Manipur boxers on shuttle run variable were 25.45 and 3.61 whereas in case with West Bengal the same were recorded as 18.63 and 3.64 respectively. There significant difference was found between Manipur and West Bengal as the calculated t-value (4.407) was more than tabulation t-value (1.725) at 0.5 level.

Table-7

SIGNIFICANCE OF MEAN DIFFERENCE BETWEEN MANIPUR AND WEST BENGAL SUB-JUNIOR FEMALE BOXERS ON THE ORIENTATION ABILITY

\begin{tabular}{|l|l|l|l|l|}
\hline Group & Sample & Mean & SD & "t $"$ \\
\hline MANIPUR & 11 & 7.07 & 0.19 & 4.123 \\
\cline { 1 - 3 } WEST BENGAL & 11 & 7.65 & 0.42 & \\
\cline { 1 - 3 }
\end{tabular}

*Significance at 0.05 level of significance i.e., $=1.725$

A perusal of table -7 indicates that a mean and standard deviation values with regard to Manipur boxers on shuttle run variable were 7.07 and 0.19 whereas in case with West Bengal the same were recorded as 7.65 and 0.42 respectively. There significant difference was found between Manipur and West Bengal as the calculated t-value (4.123) was more than tabulation t-value (1.725) at 0.5 level.

Table-8

SIGNIFICANCE OF MEAN DIFFERENCE BETWEEN MANIPUR AND WEST BENGAL SUB-JUNIOR FEMALE BOXERS ON THE BALANCE ABILITY

\begin{tabular}{|l|l|l|l|l|}
\hline Group & Sample & Mean & SD & "t" \\
\hline MANIPUR & 11 & 17.82 & 3.53 & 4.566 \\
\cline { 1 - 3 } WEST BENGAL & 11 & 8.84 & 5.47 & \\
\cline { 1 - 3 }
\end{tabular}

*Significance at 0.05 level of significance i.e., $=\mathbf{1 . 7 2 5}$

A perusal of table -8 indicates that a mean and standard deviation values with regard to Manipur boxers on shuttle run variable were 17.82 and 3.53 whereas in case with West Bengal the same were recorded as 8.84 and 5.47 respectively. There significant difference was found between Manipur and West Bengal as the calculated t-value (4.566) was more than tabulation t-value (1.725) at 0.5 level.

Table-9

SIGNIFICANCE OF MEAN DIFFERENCE BETWEEN MANIPUR AND WEST BENGAL SUB-JUNIOR FEMALE BOXERS ON THE RHYTHEM ABILITY

\begin{tabular}{|l|l|l|l|l|}
\hline Group & Sample & Mean & SD & "t" \\
\cline { 1 - 3 } & 11 & 0.14 & 0.06 & 2.448 \\
\cline { 1 - 3 } & 11 & 0.48 & 0.44 & \\
\hline
\end{tabular}

*Significance at 0.05 level of significance i.e., $=\mathbf{1 . 7 2 5}$

A perusal of table -8 indicates that a mean and standard deviation values with regard to Manipur boxers on shuttle run variable were 0.14 and 0.06 whereas in case with West Bengal the same were recorded as 0.48 and 0.44 respectively. There significant difference was found between Manipur and West Bengal as the calculated t-value (2.448) was more than tabulation t-value (1.725) at 0.5 level

\section{Conclusion}

The researcher had under taken study titled as "fat\%, BMI, BMR, $50 \mathrm{mts}$ run, shuttle run, differentiation, orientation, balance, rhythm" between Manipur and West Bengal sub-junior female boxers a profile study. Therefore from the statically analysis the following inferences were derived: No 
significant differences were observed in BMI and BMR of Manipur and West Bengal sub-junior female boxers. There were significant differences were observed in the Fat\%, Speed, shuttle run, differentiation, orientation, balance and rhythm of Manipur and West Bengal sub-junior female boxers.

\section{References}

- Archana Chahal, Sushma Ghildyal, Vijay Chahal (2012), "Predicting Excellence in Basketball: Anthropometric and Physiological Attributes In Elite Indian Female Players." International Quarterly of Sport Science 2012/1.

- Bayios, I .A, Bergeles, N.K.,Apostolidis N.G, Noutsos K.S and Koskolou, M.D. (2006), "Anthropometric, Body Composition and Somatotype differences of Greek elite female basketball, volleyball and handball players." Journal of Sports Medicine and Physical Fitness; 46(2):271-80.

- Brian A. Irving; Christopher K. Davis; David W. Brock (2008), "Effect of Exercise Training Intensity on Abdominal Visceral Fat and Body Composition." Medicine and Science in Sports and Exercise; 40(11):18631872.

- Carbuhn AF, Fernandez TE, Bragg AF, Green JS, Crouse SF (2010), "Sport and training influence bone and body composition in women collegiate athletes." Journal of Strength and Conditioning Research; 24(7):1710-7.

- Chauhan, M.S. (2004), "Prediction of performance of university throwers in relation to their anthropometric measurements." Journal of Sports and Sports Sciences; 26 (2):30-35.

- Clarke. H. Harison (1976). Application of Measurements to Health and Physical Education. $5^{\text {th }}$ Edition, Englewood Cliffs. New Jersy, Prentice Hall Inc. 1978.

- Delextrat A, Cohen D (Oct. 2009), "Strength, power, speed, and agility of women basketball players according to playing position.” Journal of Strength and Conditioning Research; 23(7):1974-81.

- Jawis, M.N. Singh, R. Singh, H.J., Yassin, M.M. (2005). Anthropometric and physiological profiles of speak takraw players. BRJ Sports Med. No; 39(11) : 825-829.

- Jelicic M, Sekulic D, Marinovic M.(2002), "Anthropometric characteristics of high level European junior basketball players.” Pub.Med;26 Suppl:69-76.

- Julian Espartero (2003), "Study on Physical Activity, Physiological, And Psychomotor Performance: Study on Variously Active Older Adult Men.” European Journal of Exercise Sciences; 68: 80-86.

- Kaur, R., Kaur, G., Deepak, Singh, J. and Singh, S. (2001). "Anthropometric and fitness profiles of Asian gold medalists male kabaddi players.” Journal of Sports and Sports Sciences; 24(2):27-37.

- Lidor R, Ziv G. (2010), "Physical and Physiological Attributes of Female Volleyball Players--A Review." Journal of Strength and Conditioning Research; 24(7):1963-73.

- Nandalal Singh and Jasveer Kaur(2011), "Lung Capacity and Body Mass Index Between Physical Education and Non-Physical Education Students- A Comparative Study." International Journal of Health, Physical Education and Computer Science in sports vol.4/1: 1-4. 
- Singh, Nandal and Kaur, Jasveer (2011). Lung Capacity and Body Mass Index Between Physical Education and Non-Physical Education Students- A Comparative Study, International Journal of Health, Physical Education and Computer Science in Sports, Volume No.4, No.1.pp1-4.

- Vishaw Gaurav, Mandeep Singh and Sukhdev Singh (2010), "Anthropometric Characteristics, Somatotyping and Body Composition of Volleyball and Basketball Players." Journalof Physical Education and Sports Management; Vol. 1(3), pp. 28-32, ISSN 1996-0794. 